\title{
REPRESENTASI MAKNA QURBAN DALAM BUDAYA POPULER Membaca Konsumerisme melalui Analisis Semiotika Barthes Iklan Cetak PKPU Kurbanmu Kendaraanmu
}

\author{
Mohamad Syahriar Sugandi \\ Prodi S1 Ilmu Komunikasi, Fakultas Komunikasi dan Bisnis, Universitas Telkom
}

Email: mohsyahriar@gmail.com

\begin{abstract}
ABSTRAK
Fenomena iklan kurban menjadi sebuah hal yang menarik dikaji terutama dikaitkan keberadaan kurban sebagai sebuah ritual ibadah, bukan sekedar komoditas barang atau jasa. Penggunaan iklan dalam menyampaikan informasi mengenai jasa layanan kurban dapat dianalisa untuk melihat bagaimana konten iklan dalam layanan jasa kurban dirancang sedemikian rupa dalam jalinan tanda yang memiliki makna tertentu, baik secara denotatif, konotatif, hingga mitos yang terkandung di dalamnya. Penelitian ini menggunakan pendekatan kritis dengan menggunakan analisis semiotika Barthes untuk membongkar makna hingga tataran ideologisnya. Iklan yang diteliti adalah iklan qurban PKPU versi Qurbanmu Kendaraanmu-mobil sport. Hasil analisis menunjukkan bagaimana penggunaan tanda dalam iklan Qurbanmu Kendaraanmu menggunakan tanda tertentu yang memiliki makna, dimana pada tataran denotatif iklan ini menjelaskan kurban sebagai sebuah bentuk ritual ibadah yang memiliki aspek teologis sekaligus sosial, di tataran konotatif bagaimana iklan mengemas simbolisasi kurban dengan tanda artifisial yang mengedepankan status sosial, dan di tataran ideologis tampak bahwa konsumerisme menjadi sebuah tanda utama yang ditampilkan secara kontradiktif dengan nilai denotatif yang dimaksudkan dalam iklan Qurbanmu Kendaraanmu.
\end{abstract}

Keyword: iklan kurban, semiotik, mitor, konsumerisme 


\section{Pendahuluan}

Idul Adha merupakan hari raya yang dipandang suci bagi umat Muslim, ibadah kurban dipandang penting dalam tradisi agama Islam karena terkait dengan perintah dan aturan yang dituangkan dalam kitab suci Al Quran, diantaranya ; Q.S. AlKautsar : 2 (perintah shalat dan berkurban), Q.S. Al Hajj : 34 (syarat hewan yang dikurbankan), Q.S. Al An'am : 121 (tata cara penyembelihan hewan kurban), dan lainnya. Dalam perspektif sejarah ibadah kurban tidak terlepas dari latar historis Nabi Ibrahim. Dalam beberapa ajaran agama lain pun ibadah kurban pun dilakukan meski tentunya masing-masing memiliki latar historis, tradisi, dan syariat atau hukum yang berbeda. Melalui ibadah kurban, seorang Muslim secara simultan menjalin hubungan vertikal dan horisontal, antara hamba dengan Tuhannya dan manusia dengan manusia lainnya.

Dalam Q.S. Al Hajj : 37 “Daging-daging unta dan darahnya itu sekali-kali tidak dapat mencapai (keridhaan) Allah, tetapi ketakwaan dari kamulah yang dapat mencapainya". Secara lugas dinyatakan bahwa ukuran ibadah kurban bukan dari ukuran lain selain ketakwaan. Meski demikian manusia memainkan simbol/tanda/lambang dalam bangunan pengalaman kehidupan mereka (animal symbolicum). Pemaknaan atas simbol seringkali mengalami pergeseran seiring dengan konstruk pengalaman manusia, terkait dengan konteks kurban dimana berkurban adalah simbol dari pengakuan/taqwa (submission of supreme-being), makna ini menjadi sebuah pesan tunggal jika dilihat dalam sudut pandang religion. Akan tetapi pemaknaan bisa saja bergeser ketika simbol-simbol tersebut berada dalam konteks sosial dimana hewan kurban menjadi center of the message. Seiring perkembangan ibadah kurban yang bersifat intim dan humanis mengalami beberapa perubahan yang sejatinya tidak mengubah pemaknaan atas keikhlasan dan kepedulian Sosial dalam pandangan Islam. Perubahan tersebut terkait erat dengan meningkatnya kemampuan ekonomi sebuah negara, perkembangan teknologi dalam segala aspek, mobilitas manusia yang semakin tinggi, serta perkembangan perspektif komunikasi dan kebudayaan. 
Peneliti melihat sebuah fenomena yang muncul beberapa tahun ke belakang di Indonesia, dimana kemunculan lembaga donor dan lembaga pengelolaan dana ummah (umat) bermunculan seiring dengan krisis ekonomi yang melanda Indonesia di tahun 1998, lebih lanjut fenomena yang hadir bersamaan adalah terkait dengan penyedia jasa terkait dengan ibadah kurban bermunculan dengan cukup signifikan yang banyak dilakukan oleh Lembaga Amil Zakat dan bentuk organisasi lainnya. Beberapa Amil Zakat yang seringkalijuga melakukan pelayanan jasa ibadah kurban diantaranya : Dompet Peduli Ummat-Daarut Tauhid, Dompet Dhuafa Republika, Pos Keadilan Peduli Umat (PKPU), dan banyak lainnya. Selain itu badan resmi dari pemerintah yaitu Badan Amil Zakat Nasional juga ikut melakukan pelayanan jasa qurban. Ada beberapa yang fokus pada pendistribusian, tetapi banyak juga yang termasuk menyediakan jasa pelaksanaan kurbannya. Kehadiran lembaga-lembaga ini tentunya memberikan kemudahan bagi kita dalam melakukan ibadah kurban, bahkan penyebaran yang tersistematis memungkinkan daging kurban didistribusikan dengan lebih luas dan tahan lama seperti misalnya dikemas menjadi daging kurban kalengan. Seiring dengan kehadiran badan atau organisasi penyedia layanan jasa kurban maka wajar dibutuhkan bentuk komunikasi kepada khalayak, salah satunya melalui iklan. Bentuk komunikasi iklan tentunya dengan pandangan praktis bahwa hal ini dilakukan sebatas agar masyarakat lebih aware dan terinformasikan dengan baik mengenai layanan jasa kurban tersebut.

Membahas komunikasi melalui sudut pandang ekonomi atau spesifiknya pasar, tentu tidak terlepas dari iklan. Iklan sebagai sebuah bentuk bauran promosi yang menjadi bagian esensial dari bauran pemasaran. Iklan menjadi salah satu alat komunikasi bagi para pemilik barang dan jasa untuk menyampaikan pesan secara luas dan massif. Pesan yang disampaikan tidak terlepas dari upaya menyampaikan informasi dan membentuk persepsi yang akan mempengaruhi keputusan konsumen dalam melakukan pembelian atau konsumsi. Iklan digunakan secara mendasar untuk identifikasi sebuah produk, menyampaikan informasi, dan melakukan persuasi kepada calon konsumen. Pertanyaan 
berikutnya adalah bagaimana iklan yang merepresentasikan sebuah budaya konsumerisme berhadapan dengan sebuah konsep ibadah kurban yang secara filosofis berangkat tidak dari pendekatan supply dan demand layaknya sebuah komoditas. Penelitian ini melihat apakah tanda dalam iklan yang digunakan memiliki pengaruh dari ideologi tertentu. Iklan sebagai sebuah simbol atau tanda, tentu dapat dianalisa ke dalam tataran makna denotatif, konotatif, dan mitos/ideologis-nya. Semiologi Barthes akan digunakan untuk melihat apakah terdapat sebuah kandungan mitos atau ideologi dalam iklan kurban, yang kontradiktif dengan pemaknaan pesan utamanya sebagai sebuah simbolisasi ritual yang berdasar kepada konsep ketakwaan.

\section{Kajian Pustaka}

\section{Makna Kurban}

Kurban atau qurb dalam bahasa Arab memiliki arti dekat atau mendekati. Dalam kajian ilmu fiqih berkurban dapat diartikan sebagai tindakan menyembelih binatang di waktu matahari sedang naik di pagi hari atau disebut juga udhiah - yang berasal dari kata dahwah atau duha ( waktu matahari naik di pagi hari). Menurut M. Quraish Shihab (2002:30) , qurban pertama kali yang terjadi di muka bumi ini adalah qurban yang diselenggarakan oleh dua putera Nabi Adam (Habil dan Qabil) kepada Allah. Meski demikian tradisi kurban dalam tradisi Islam secara formal bermula dari Nabi Ibrahim As. Peristiwa kenabian ini menjadi fondasi dalam memaknai ibadah kurban sebagai sebuah simbolisasi imanen, bentuk ketakwaan dan ketauhidan terhadap Tuhan. Makna ibadah kurban melalui cara pandang ini menjadi bentuk pertama dalam pemaknaan kurban sebagai sebuah perspektif teologis atau hubungan vertikal dengan Tuhan.

Bentuk pemaknaan berikutnya menempatkan ibadah kurban sebagai bentuk nyata kepekaan sosial dalam struktur masyarakat. Secara sosial-kemasyarakatan, ibadah kurban menempatkan strata sosial mereka yang secara relatif tinggi atau memiliki kemampuan untuk melakukan ibadah kurban, agar membagikan daging kurban kepada mereka yang 
berhak menerimanya - dalam hal ini dapat dilihat mereka yang secara strata sosial ekonomi rendah atau belum mampu. Tradisi ini menjadi sebuah bentuk mengasah kepekaan dan kepedulian sosial. Ibadah kurban dalam batasan tertentu dapat diposisikan sebagai sebuah upaya untuk menjembatani perbedaan antara kelompok sosial dalam strata sosial ekonomi.

Pembagian hewan kurban bisa menjadi sarana untuk membentuk masyarakat yang toleran, sebagai medium redistribusi kesejahteraan dan berpotensi mengikis tembok segregasi antara kaya dan miskin. Sejalan dengan filosofis teologis ibadah kurban sebagai bentuk ketakwaan, maka menjadi paripurna ketika kerelaan dan keikhlasan orang-orang yang melaksanakan ibadah kurban berimbas pada perilaku keseharian dan perhatiannya pada sesama, utamanya kaum miskin dan mustadzafiin. Perspektif dalam memaknai kurban sebagai sebuah bentuk upaya manusia untuk menjadi manusiawi ini yang dimaksud sebagai perspektif sosial atau hubungan horisontal antar sesama manusia.

Kembali kepada esensinya maka ibadah kurban dimaksudkan untuk memperkuat dan mempertebal ketakwaan kepada Allah dimana ibadah kurban sebagai wujud ketakwaan hamba kepada-Nya. Hal ini dijelaskan oleh Allah dalam firman-Nya: "Daging-daging unta dan darahnya itu sekali-kali tidak dapat mencapai (keridhaan) Allah, tetapi ketakwaan dari kamulah yang dapat mencapainya." (QS Al Hajj, 22: 37) secara literal dapat ditafsirkan bahwa alat ukur dalam ibadah kurban cenderung tidak dalam konteks kuantitas melainkan kualitas. Dimana bukanlah suatu nilai hewan kurban yang tinggi pun banyak (kuantitas) sebagai tolak ukur utama di mata Allah, karena kurban yang banyak tetapi tanpa keikhlasan dan ketakwaan orang yang berkurban maka hal itu sama saja tak ternilai di mata Allah SWT. Berdasarkan dua perspektif ; teologis dan sosial maka ibadah kurban memiliki pemaknaan yang sangat ilahiah sekaligus membumi. Tidak sebatas ritual ibadah melainkan juga mengandung konteks humanistis. Dengan kata lain, aplikasi ibadah kurban secara ideal dilandasi oleh semangat keikhlasan dan kemanusiaan.

Konsumerisme 
Masyarakat konsumsi tidak terlepas dari berbagai konsep dalam ilmu ekonomi yang memandang masyarakat dalam dualisme produksi dan konsumsi. Maslow membagi kebutuhan dalam tingkatan piramida kebutuhan, meski demikian konsep mengenai kebutuhan dasar (primer), sekunder pun tersier secara mendasar memiliki derajat relatifitas tersendiri. Relatif yang dimaksud disini merupakan kenyataan dimana pemenuhan kebutuhan meski secara esensi terkait dengan keberlangsungan hidup mahluk hidup khususnya terkait kebutuhan dasar, seringkali pada praktiknya pemenuhan kebutuhan tidak berarti pasti harus dipenuhi secara berurutan. Seseorang mungkin saja melakukan konsumsi sebuah barang yang bukan sebuah kebutuhan dasar dengan mengorbankan basic needs tersebut. Tidak sedikit orang yang memilih untuk mengurangi kebutuhan dasar mereka untuk memampukan mereka dalam mengkonsumsi barang lain di tingkat kebutuhan yang lebih atas (sekunder-tersier-dan selanjutnya), logika mayarakat dalam melakukan tindakan konsumsî, secara nyata tidak selogis penggambaran Maslow.

Pendekatan Marxisme dalam memandang hubungan antara produksi dan konsumsi dijelaskan Marx melalui perbedaan antara nilai guna dan nilai tukar terhadap sebuah komoditas atau barang. Nilai guna menekankan kepada fungsionalitas sebuah komoditi, pada kemampuan mendasar yang dimilikinya sebagai sebuah ciri melekat dan utama dari barang tersebut. Nilai tukar disisi lain merujuk kepada nilai yang dimiliki oleh suatu komoditas ketika barang tersebut ditukarkan atau dibandingkan dengan komoditas lainnya. Marx menjelaskan bahwa nilai guna adalah sebuah hubungan antara komoditas dan konsumen, yang terwujud dalam sebuah tindakan konsumsi. Sedangkan nilai tukar menurut Marx yang secara sederhana sebagaimana dijelaskan oleh Kathy Myers (2012:161) adalah mengekspresikan hubungan antara komoditas dan tenaga kerja produksi. Teori Marxis secara tradisional memandang konsumsi lebih rendah dibandingkan dengan produksi. Dalam tradisi pemikiran ekonomi positif maupun Marxis memandang bahwa tindakan konsumsi sebagai sebuah area yang dikesampingkan, sebuah false consciousness, sebuah area subjektif. 
Pandangan lain dalam menelisik hubungan konsumsi dan produksi dijelaskan melalui teori Utilitas Marjinal ${ }^{1}$. Nilai komoditas hanyalah merupakan penilaian subjektif yang diberikan kepada mereka oleh pelbagai individu-tingkat utilitas yang dimiliki oleh komoditas tersebut bagi masing-masing individu. (Myers, 2012: xiv). Keynes pada 1930-an melakukan perombakan dan reposisi atas teori konsumsi dimana tindakan pilihan konsumen bersifat sentral bagi persamaan ekonomi, khususnya kebutuhan untuk menstimulasi permintaan dan menghindari kurangnya tingkat konsumsi (Myers, 2012: xvi). Pada akhirnya memunculkan berbagai upaya stimuli dalam memunculkan permintaan atau demand, periklanan sebagaimana yang dikenal saat ini.

Baudrillard memegang peranan penting, khususnya dalam membangun sebuah pendekatan berbeda terkait dengan perilaku konsumsi. Baudrillard menjelaskan secara komprehensif apa yang menjadi dasar lahirnya konsumerisme. Baudrillard menelaah keadaan sosial ekonomi masyarakat sebagai sebuah wacana semiotik. Pemikiran tersebut dibagi atas periode kritis yang memaparkan koreksinya atas teori Marx dan masyarakat konsumer, serta periode simulasi yang memaparkan tentang simulasi dan simulacra.

Masyarakat konsumer dijelaskan oleh Baudrillard dengan mengadopsi dasar pemikiran Marx mengenai use value dan exchange value. Bahwa sebuah benda selain memiliki dua nilai tersebut, juga memiliki symbolic value dan sign value. Baudrillard menjelaskan bahwa symbolic value adalah logika kemenduaan yang sejalan dengan nilai simbolik, berhubungan dengan hubungan subjek dengan subjek lain. Sedangkan sign value adalah logika perbedaan yang sejalan dengan nilai tanda, yang menempatkan objek lain yang berhubungan dengan tanda lainnya. Berbeda dengan pandangan Marx, Baudrillard berpendapat bahwa konsumsilah yang menjadi inti ekonomi, bukan produksi. Baudrillard mendasari pandangan mengenai objek berdasarkan teori ekonomi positif dimana preferensi subjektif berlaku dalam sebuah tindakan konsumsi. Tetapi kritik

${ }^{1}$ Konsep mengenai kepuasan marjinal dalam ilmu ekonomi, dimana perubahan utilitas atau kegunaan yang terjadi karena adanya perubahan konsumsi suatu barang sebesar satu satuan unit 
mendalam yang dilakukan Baudrillard melalui penjelasan mengenai sign value, mengarah kepada yang disebut dengan ekonomi adiktif, dimana orang lebih suka dan cenderung menjadi pecandu konsumsi daripada menjadi seorang pelaku produksi. Sebuah objektivasi dari hasil dan produksi yang dimasifikasi melalui iklan. Baudrillard melihat bagaimana orang memposisikan diri sebagai subjek atas objek dalam sebuah iklan. Nilai akan objek dan tanda sebagaimana digambarkan Marx melalui sebuah hubungan romantisme antara objek dan pelaku produksi menjadi sebuah hubungan vulgar konsumsi berlebih - perilaku adiktif konsumsi tanda.

Kegiatan ekonomi yang berbasis pada konsumsi sign value, menempatkan manusia dalam keadaan yang lebih memilih untuk mengonsumsi tanda daripada melihat kegunaan objek itu sendiri. Masyarakat konsumer - sebagaimana diistilahkan Baudrillard - yang bercirikan proses objektivasi dimana status sosial menggantikan kedudukan sosial yang berdasar pada ras, gender, dan kelas. Seseorang mampu mendapatkan prestise dari konsumsi tanda yang ia lakukan terlepas dari ras, gender, dan kelasnya. Konsumsi tidak sama dengan kegiatan membeli. Kegiatan membeli didasarkan pada use value, sedangkan konsumsi didasarkan pada sign value. Konsumerisme dapat dijelaskan secara sederhana, ketika komoditas diproduksi sebagai suatu tanda, dan tanda-tanda itu dikonsumsi sebagai sebuah komoditas.

Lebih lanjut sebuah kalimat yang ditulis oleh Baudrillard dalam Ekstasi Komunikasi ( Baudrillard, 2006 : 3-4) sebagai berikut “... mobil Andalah yang bicara pada Anda, yang secara spontan dapat memberitahukan bagaimana keadaannya dan bagaimana pula keadaan Anda (meskipun kadang-kadang dia tidak dapat berfungsi dengan baik jika Anda tidak memfungsikannya secara benar)...mobil ini menjadi sesuatu (atau bisa menjadi "seseorang", karena pada tahap ini keduanya tidak dapat dibedakan lagi)..." . Baudrillard menjelaskan bahwa dalam sebuah periode simulasi adalah ketika terdapat hal yang nyata dan tidak nyata. Hal yang nyata ini diperlihatkan melalui model konseptual yang berhubungan dengan mitos, yang tidak dapat dilihat kebenarannya dalam sebuah 
kenyataan. Segala sesuatu - tanda - yang menarik perhatian masyarakat konsumen. Ketika mobil menjadi "sesuatu", ketika utilitas tidak lagi didasari kepada use value melainkan kepada konsumsi tanda, sehingga terjadi percampuran antara kenyataan dengan simulasi dan menciptakan hiperealitas di mana yang nyata dan tidak nyata menjadi tidak jelas.

Masyarakat secara tidak sadar sudah terpengaruh oleh simulasi - sebuah tiruan - dan tanda (simulacra) yang ada di tengah-tengah kehidupan mereka. Pada saat mobil dikemas menjadi sebuah bentuk komunikasi iklan mobil yang didalamnya juga tersemat sebuah tanda maskulinitas, maka secara tidak sadar masyarakat konsumer menginginkan semua yang ada di iklan itu, baik mobil dalam sisi fungsionalitasnya ataupun mobil sebagai sebuah tanda untuk menjadi maskulin, hal inilah yang disebut simulacra. Sehingga secara tidak sadar masyarakat ditekankan pada peran bagaimana mobil menciptakan tanda yang perlu dikonsumsi untuk kemudian direproduksi sebagai sebuah makna tanda lainnya.

Perkembangan teknologi transportasi dan komunikasi membawa umat manusia ke dalam sebuah realita baru yang secara singkat mengerucut pada kata globalisasi. Dalam konsep supply dan demand mereka pemilik faktor produksi tentu saja menjadi pihak yang mampu untuk mendominasi. Para pemilik ini menjadikan keunggulan produksi sebagai sebuah keniscayaan dalam mencapai kesejahteraan. Tahapan berikutnya dalam konteks masyarakat modern adalah keberadaan informasi sebagai sebuah komoditas. Kini bentuk baru hegemoni tercipta melalui dominasi komoditas informasi melalui globalisasi, dimana semakin banyak informasi - baca tanda - dikuasai, dikemas, dan di-diseminasi atau dikonsumsi yang mengarah kepada penciptaan sebuah pasar baru. Dimana tanda secara dominan dan agresif menjadi sebuah objek untuk dikonsumsi secara massif. Baudrillard ${ }^{2}$ menyatakan “... Dengan menelan makna, informasi, dan transparansi secara rakus, masyarakat kita telah mampu melampaui titik batas, yaitu ekstasi permanen : ekstasi sosial (massa), tubuh (kegemukan), seks (kecabulan), kekerasan (teror), dan informasi

2 dalam Ekstasi Komunikasi (2006:75) 
(simulasi)...Jika seseorang tidak mampu lagi menyatukan benda-benda dengan hakikatnya, itu karena benda-benda tersebut telah mencemooh dan melampaui definisi mereka sendiri. Segala sesuatu menjadi lebih sosial daripada yang-sosial (massa), lebih gemuk daripada yang-gemuk (obesitas), lebih kejam daripada yang-kejam (teror), lebih seksual daripada seks (porno), lebih riil daripada-yang riil (simulasi), dan lebih cantik daripada yang-cantik itu sendiri (fashion)."

\section{Komodifikasi Tanda dalam Iklan}

Iklan secara sederhana merupakan sebuah upaya melakukan pembentukan persepsi atas sebuah objek melalui pengunaan tanda-tanda tertentu. Iklan memiliki tiga fungsi dasar yaitu ; mengingatkan identitas, melakukan persuasi (perubahan persepsi), dan memberikan informasi. Iklan menggunakan berbagai macam tanda dalam menyampaikan sebuah pesan yang akan diterima oleh audiens.

Dalam konteks masyarakat konsumsi sebagaimana dipahami melalui cara pandang Baudrillard, maka posisi iklan menjadi strategis dalam menyampaikan tanda untuk dikonsumsi oleh khalayak, dimana tanda menjadi sebuah pesan yang diproduksi oleh para pemilik tanda. Hal yang menarik adalah posisi iklan sebagai sebuah medium komunikasi massa dimana iklan secara karakteristik merupakan sebuah bentuk komunikasi yang ditujukan kepada publik atau khalayak luas, sehingga penggunaan tanda dalam sebuah iklan harus mampu dimaknai dalam sebuah tataran umum, sehingga konten iklan biasanya bersifat tidak personal atau pribadi. Singkat kata iklan harus mampu mewakili pemahaman secara umum bagi para pembacanya.

Perkembangan iklan sendiri tidak terlepas dari pemikiran Keynes mengenai teori

konsumsi, yang diperankan sebagai sebuah upaya menyeimbangkan permintaan dan penawaran. Perkembangan dalam industri periklanan terkait erat dengan kondisi struktural perekonomian yang berlaku. Kondisi Perang Dunia Pertama membawa ekonomi global kedalam kondisi lesu, lebih jauh kepada situasi depresi khususnya bagi perekonomian 
Amerika. Kondisi ini menjadikan peranan iklan sebagai sebuah alat untuk menciptakan permintaan. Gillian Dyer dalam Myers (2012:8), menggarisbawahi bahwa untuk menutupi gap antara supply dan demand adalah dengan memberikan rangsangan misalnya skema pembelian secara cicilan/kredit. Konsumen diposisikan sedemikian rupa dalam sebuah upaya manipulatif untuk menciptakan rasa bersalah dengan tidak menjadi konsumtif (membeli barang yang tidak berdasar kepada logika kegunaan pun mereduksi waktu guna sebuah barang dengan dalih trend).

Bennet dalam bukunya Posters and Showcards ${ }^{3}$ menyatakan bahwa iklan harus ditujukan bagi kelas sosial tertentu. Iklan yang memposisikan dirinya sebagai sebuah medium komunikasi dalam menyampaikan pesan mengenai sebuah komoditas secara kontradiktif menjadi sebuah pesan yang dikonsumsi sebagai sebuah "komoditas". Sebagaimana Baudrillard menjelaskan simulasi, "komoditas" iklan menjadi lebih nyata dibandingkan kenyataan dari komoditas yang diiklankan.

Penekanan kualitas produk dan manusia alamiah sebagai dasar rasionalitas konsumen, digantikan oleh logika hasrat. Motivasi dianggap sebagai driven factor dalam menciptakan daya beli, dimana motivasi tersebut digerakkan secara sistematis oleh hasrat artifisial. Kebutuhan digantikan oleh keinginan. Citra menggantikan hal yang nyata. Tanda menjadi nilai tukar utama dalam menciptakan eksistensi. Sebuah komodifikasi tanda. Vance Packard ${ }^{4}$ menggambarkan bagaimana iklan menjadi antek industri, bertempur tanpa belas kasihan untuk mendapatkan isi dompet konsumsi. Tanda-tanda yang digunakan secara emosionil dalam sebuah iklan menciptakan sebuah kesan sebagai panduan bagi konsumen untuk melakukan konsumsi gaya hidup. Pendekatan psikologi dan sosiologi, yang dikemas dalam sebuah bentuk komunikasi membentuk sebuah persepsi dalam benak konsumen. Ketika perbedaan produk menjadi semakin sulit dibedakan, persepsi menjadi memegang

\footnotetext{
Myers 2012: 9
}

${ }^{4}$ dalam Myers $2012: 23$ 
peranan penting. Use value menjadi tidak signifikan ketika symbolic value menjadi semakin mengemuka. Mike Featherstone dalam bukunya Theory, Culture, and Society ${ }^{5}$ menyatakan "Makna barang-barang tidak dapat...dipahami dengan merujuk kualitas intrinsiknya atau kegunaan yang telah ditetapkan sebelumnya, sebaliknya barang-barang tersebut menjadi tunduk pada proses simbolisasi dan resimbolisasi terus-menerus." Myers (2012:175) menjelaskan bahwa individu tidak lebih merupakan objek yang dengannya mereka melakukan identifikasi. Objek yang kita konsumsi sebagai representasi eksistensi diri kita, sebuah gambaran atas dunia yang terfiksasi oleh objek.

\section{Iklan dalam Semiologi}

Semiotik atau semiologi merupakan istilah yang merujuk kepada ilmu yang mempelajari sistem tanda seperti bahasa, kode, sinyal, dan sebagainya. Secara sederhana semiotika adalah ilmu tentang tanda, diambil dari kata Yunani seemion yang berarti tanda. Sebagaimana telah disebutkan manusia dalam kehidupannya memiliki kemampuan untuk menghasilkan dan memproses berbagai simbol. Samovar ${ }^{6}$ menyebutkan kemampuan ini mencakup menerima, menyimpan, mengolah, dan menyebarkan simbol-simbol yang membedakan manusia dari mahluk hidup lainnya. Semiotika menelaah simbol/ tanda, mempelajari fungsi tanda dalam sebuah teks dimana sistem tanda yang terkandung dalam sebuah teks memiliki kandungan pesan yang mengarahkan pembacanya dalam menangkap isi pesan tersebut. Teks dalam hal ini mencakup apa yang disampaikan Chandler ${ }^{7}$ sebagai kumpulan tanda-tanda (seperti kata-kata, gambar, suara dan atau gerakan) yang dikonstruksikan (dan diinterpretasikan) dengan mengacu pada konvensi yang terkait dengan genre dan media komunikasi tertentu.

\footnotetext{
${ }^{5}$ Myers $2012: 174$

${ }^{6}$ dalam Vera $2014: 6$

${ }^{7}$ Dalam Vera, 2014: 8
} 
Konsep ini diawali oleh pemikiran Ferdinand Saussure sebagai seorang linguist yang melihat semiotika sebagai ilmu untuk mengkaji tanda, proses menanda, dan menandai, melalui sistem tanda yang dikelompokkan menjadi dua yaitu : Penanda dan Petanda, sebuah model yang dikembangkan oleh Saussure melihat bagaimana Penanda sebagai sebuah bentuk persepsi dari sebuah tanda atau citra tanda. Sedangkan Petanda adalah bentuk konsep mental terkait dengan tanda tersebut. Hubungan diadik antara penanda dan petanda bersifat arbitrer, sebuah hubungan suka-suka bukan sebuah hubungan yang terpolakan dengan baku. Meski demikian Saussure menegaskan bahwa relasi yang terbentuk antara penanda dan petanda tidak berarti bersifat pribadi melainkan sebuah bentuk dari kesepakatan sosial.

Hubungan antara penanda dan petanda merupakan sebuah kesatuan dari komponen tanda dimana hubungan antara keduanya sebagaimana disebutkan oleh Saussure sebagai makna. Misalnya kata " Hot" sebagai sebuah penanda ketika disematkan dalam Petanda kompor maka akan menjadi pemaknaan mengenai panas kompor ketika menyala dan berbahaya dipegang tangan secara langsung. Tetapi ketika disematkan dalam Petanda lain misalnya chicken wing - menjadi hot chicken wing - maka makna yang dihasilkan menjadi tingkat kepedasan dari sebuah makanan.

Hasil pemikiran Saussure ini yang kemudian menjadi sebuah pondasi bagi Barthes untuk mengembangkan lebih lanjut mengenai penerapan semiotika atau semiologi sebagai sebuah ilmu. Berbeda dengan Saussure yang fokus pada hubungan kesatuan antara penanda dan petanda, dan makna yang diungkap dalam hubungan diadik tersebut, Barthes melihat lebih jauh mengenai konsep penandaan pada tataran yang lebih dalam (konotatif), dimana sebelumnya Saussure melihat terutama pada tataran denotatif. Roland Barthes melihat bahasa sebagai sebuah sistem tanda yang mencerminkan asumsi-asumsi dari masyarakat tertentu dalam waktu tertentu (Sobur, 2003 : 63).

Sebagaimana pandangan Saussure, Barthes juga meyakini bahwa antara penanda dan petanda tidak terbentuk secara alamiah, melainkan bersifat arbitrer. Bila Saussure hanya 
menekankan pada penandaan dalam tataran denotatif, maka Roland Barthes menyempurnakan semiologi Saussure dengan mengembangkan sistem penandaan pada tingkat konotatif. Barthes juga melihat aspek lain dari penandaan, yaitu mitos yang menandai suatu masyarakat.

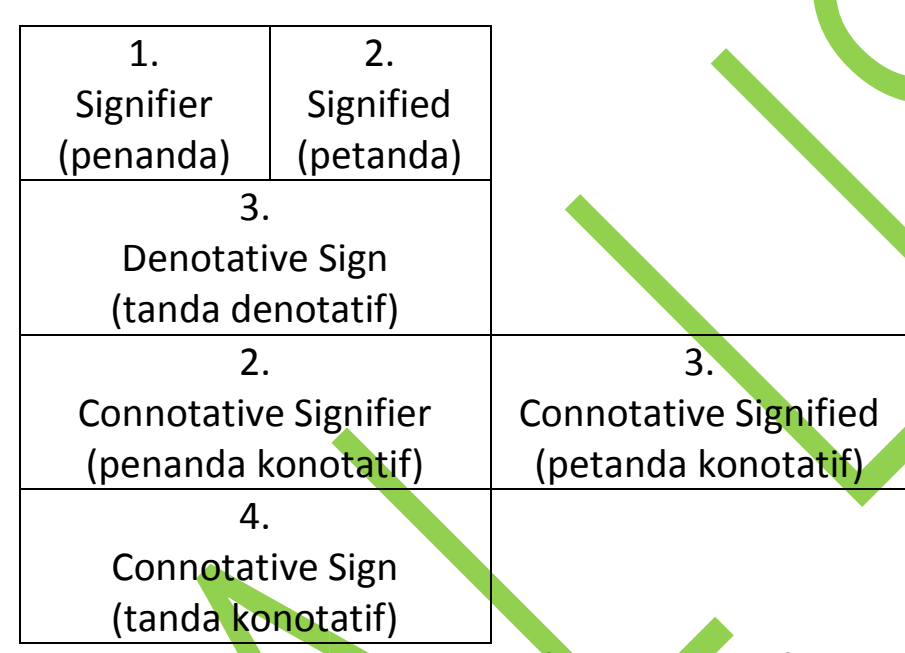

Tabel 1. Peta Tanda Barthes (Sobur, 2003 : 69)

Dalam peta tanda yang dikembangkan Barthes maka dapat dilihat bagaimana tanda denotatif (3) terbentuk dari relasi antara penanda (1) dan petanda (2). Akan tetapi, pada saat bersamaan, tanda denotatif juga menjadi sebuah penanda konotatif (4). Denotasi dalam pandangan Barthes merupakan tataran pertama yang maknanya bersifat tertutup. Tataran denotasi menghasilkan makna yang lugas, langsung, dan pasti. Denotasi merupakan makna yang sebenar-benarnya atau harfiah, yang disepakati bersama secara sosial, yang rujukannya pada realitas.

Tanda konotatif merupakan sebuah tanda yang dibangun melalui relasi dimana penandanya mempunyai makna yang implisit (tersamar), tidak langsung, dan tidak pasti, artinya terbuka kemungkinan terhadap penafsiran-penafsiran baru. Dalam semiologi Barthes, Relasi dalam Tanda denotatif dijelaskan oleh Barthes sebagai sistem signifikansi tingkat pertama, sedangkan Tanda konotatif merupakan sistem signifikansi tingkat kedua. 
Denotasi dapat dikatakan merupakan makna objektif yang tetap, sedangkan konotasi merupakan makna subjektif dan bervariasi.

Barthes menambahkan pemikiran mengenai makna tanda, melalui signifikansi tahap kedua yang mengungkap makna konotasi yaitu makna bermakna subjektif atau paling tidak intersubjektif, yang berhubungan dengan isi, tanda bekerja melalui mitos yang merupakan lapisan Petanda dan makna yang paling dalam. Dikembalikan dalam tanda "hot" sebagaimana diungkap di atas, penyematan penanda dalam petanda "kompor" akan memunculkan makna tanda denotatif panas kompor ketika menyala, tetapi makna baru secara konotatif - dapat muncul ketika penanda "hot" disematkan pada petanda " wanita dan atau sensualitas" ketika makna konotatifnya menjadi seorang wanita yang seksi dan "membakar" nafsu.

Terdapat perbedaan antara memaknai denotasi dan konotasi ala Barthes dengan arti denotasi dan konotasi pada umumnya. Secara umum denotasi diartikan sebagai sebuah makna harfiah sebuah objek, sebuah proses signifikansi tradisional, biasanya mengacu kepada penggunaan bahasa dengan arti yang sesuai dengan apa yang terucap. Akan tetapi, di dalam semiologi Barthes denotasi merupakan sebuah sistem signifikansi tingkat pertama, sementara konotasi merupakan tingkat kedua. Dalam hal ini denotasi adalah ketertutupan makna atau ditutupi (represi) dalam makna politis, khas kritik Barthes. Sebagai reaksi yang paling ekstrem melawan keharfiahan denotasi yang bersifat opresif ini, Barthes mencoba menyingkirkan dan menolaknya, bagi Barthes yang ada hanyalah konotasi semata-mata. Lebih lanjut, dalam kerangka Barthes konotasi identik dengan operasi ideologi, yang disebutkannya sebagai mitos dan berfungsi untuk mengungkapkan dan memberikan pembenaran bagi nilai-nilai dominan yang berlaku dalam suatu periode tertentu ${ }^{8}$. Mitos menurut Barthes juga merupakan sebuah sistem pemaknaan tataran ke-dua.

\footnotetext{
${ }^{8}$ Budiman dalam Sobur, $2003: 71$
} 
Mitos dalam pandangan Barthes berbeda dengan konsep mitos dalam arti umum. Barthes mengemukakan mitos adalah bahasa, maka mitos adalah sebuah sistem komunikasi dan mitos adalah sebuah pesan. Dalam uraiannya, ia mengemukakan bahwa mitos dalam pengertian khusus ini merupakan perkembangan dari konotasi. Konotasi yang sudah terbentuk lama di masyarakat itulah mitos. Barthes ${ }^{9}$ mengatakan bahwa mitos merupakan sistem semiologis, yakni sistem tanda-tanda yang dimaknai manusia. Mitos dapat dikatakan sebagai produk kelas sosial yang sudah memiliki suatu dominasi. Mitos Barthes dengan sendirinya berbeda dengan mitos yang kita anggap tahayul, tidak masuk akal, ahistoris, dan lain-lain, tetapi mitos menurut Barthes sebagai type of speech seseorang. Dalam mitos memungkinkan untuk sebuah Petanda memiliki banyak Penanda, misalnya "sensualitas" dapat memiliki banyak penanda mulai dari penyematan kata hot pada objek tertentu, poster Marylin Monroe, hingga seekor kuda jantan.

\section{Iklan, Representasi, dan Ideologi}

Media cetak merupakan salah satu medium yang seringkali digunakan dalam beriklan, yang tidak terlepas dari kehadiran mesin Guttenberg. Secara umum iklan melalui media cetak tentunya memiliki karakter khasnya sendiri, misalnya harus memiliki stopping power atau eye catching, sesuatu kekuatan yang dapat mencuri atau menarik perhatian khalayak pembacanya. Biasanya terletak pada aspek desain kreatif dalam layout iklan tersebut. Dalam iklan cetak yang akan diteliti seluruh bagian atau elemen dari iklan cetak akan menjadi bagian dari unit analisa. Dimana setiap elemen iklan diasumsikan sebagai tanda dan memiliki susunan sistem tanda dengan hubungan makna dan tanda-tanda sendiri. Dimana elemen ini dilihat sebagai sebuah jalinan tanda yang saling berkaitan sehingga memunculkan sebuah pemaknaan baik dalam tataran denotasi maupun konotasi menurut Barthes. Beberapa hal yang dilihat dalam penelitian ini selain visualisasi penyajian, juga

${ }^{9}$ dalam Vera 2014: 28 
mempertimbangkan komponen warna, dimana warna dilihat sebagai sebuah pelengkap gambar serta mewakili suatu suasana/ nuansa/ ambience yang ingin dibangun pembuat pesan.

Sebagai bagian dari produk komunikasi, iklan merupakan sebuah proses penyampaian pesan, dimana pesan tersebut berisi informasi tentang suatu produk, baik barang, dan jasa. Iklan disampaikan secara persuasi dan bertujuan untuk mempengaruhi khalayak, dimana biasanya iklan disampaikan melalui medium yag menjangkau luas dan massif, cenderung disusun dalam bentuk pesan non-personal, dan berbayar. Beberapa definisi iklan, yaitu menurut Lee dan Johnson ${ }^{10}$ " iklan adalah komunikasi komersil dan nonpersonal tentang sebuah organisasi dan prduk-produknya yang ditransmisikan ke suatu khalayak target melalui media yang bersifat massal, seperti televisi, radio, koran, majalah, direct mail, reklame luar ruang, atau kendaraan umum (transportasi publik). Definisi lain dijelaskan Sudiana dalam Vera (2014: 43) yaitu iklan sebagai salah satu bentuk komunikasi yang terdiri atas informasi dan gagasan tentang suatu produk yang ditujukan kepada khalayak secara serempak agar memperoleh sambutan baik, iklan berusaha memberikan informasi, membujuk, dan meyakinkan. Marchand menjelaskan dalam Vera (2014:43) menjelaskan bahwa tidak ada iklan yang ingin menangkap kehidupan seperti adanya, tetapi selalu ada maksud untuk memotret ideal-ideal sosial, dan merepresentasikan sebagai sesuatu yang normatif, seperti kebahagiaan, kepuasan. Sebagai sebuah medium komunikasi, iklan memiliki kemampuan untuk menangkap, mengemas, dan menyajikan realitas kehidupan. Di satu sisi realitas atau pengalaman sosial yang dialami dalam kehidupan dapat terpotret dalam produk iklan. Tidak sedikit iklan merepresentasikan sebuah realitas sosial.

Representasi atau representation berarti perwakilan, gambaran, atau penggambaran, dimana dapat diartikan sebagai gambaran mengenai suatu hal yang terdapat dalam kehidupan yang digambarkan melalui suatu media. Representasi menurut Chris Barker

${ }^{10}$ dalam Vera, $2014: 43$ 
adalah konstruksi sosial yang mengharuskan kita mengeksplorasi pembentukan makna tekstual dan menghendaki penyelidikan tentang cara dihasilkannya makna pada beragam konteks. Representasi dan makna budaya memiliki materialitas tertentu. Mereka melekat pada bunyi, prasati, objek, citra, buku, majalah, dan program televisi. Mereka diproduksi, ditampilkan, digunakan, dan dipahami dalam konteks sosial tertentu ${ }^{11}$ Yasraf dalam Vera (2014 : 97) menjelaskan bahwa representasi pada dasarnya adalah sesuatu yang hadir, namun menunjukkan sesuatu di luar dirinyalah yang dia coba hadirkan. Representasi tidak menunjuk kepada dirinya sendiri, namun kepada yang lain.

Dalam konteks kebudayaan representasi tertentu biasanya ditampilkan sebagai sebuah penunjukkan pemikiran tertentu, seperti sensualitas ditunjukkan oleh berbagai petanda yang tersemat di dalamnya. Petanda ini merepresentasikan sesuatu, sebagaimana halnya sensualitas itu sendiri dapat menjadi sebuah penanda dari sebuah petanda baru misalnya komodifikasi seks. Sejalan dengan pemahaman Barthes mengenai mitos yang tidak terlepas dari keberadaan ideologi, maka ideologi menjadi sebuah kerangka berpikir yang melekat yang dapat direkam dan dicatat melalui berbagai produk pemikiran tersebut, salah satunya melalui produk budaya. Ideologi menurut Frans Magnis dalam Vera (2014: 97) adalah keseluruhan sistem berpikir, nilai-nilai dan sikap dasar rohaniah sebuah gerakan kelompok sosial atau individu. Ideologi dapat dimengerti sebagai suatu sistem penjelasan tentang eksistensi seuatu kelompok sosial, sejarahnya, dan proyeksinya ke masa depan, serta merasionalkan suatu bentuk hubungan kekuasaan. Ideologi adalah sebuah doktrin yang membimbing tindakan politik, identitas-identitas yang mesti diyakini sebagai "iman" politik, tujuan yang wajib dicapai, alasan yang harus diperjuangkan, dan visi tentang masyarakat terbaik yang niscaya diwujudkan. ${ }^{12}$

${ }^{11}$ Barker dalam Vera, 2014 : 97

${ }^{12}$ Adam dalam Vera, 2014: 97 


\section{Metode Penelitian}

Penelitian ini menggunakan pendekatan kualitatif melalui analisis semiotika dalam perspektif Barthes. Subjek penelitian adalah iklan qurban PKPU versi kurbanmu kendaraanmu - Mobil Sport, sedangkan objek penelitian adalah tanda yang terkandung dalam iklan qurban PKPU versi kurbanmu kendaraanmu - Mobil Sport. Penelitian pada dasarnya merupakan suatu upaya ilmiah untuk memahami dan memecahkan masalah atau fenomena. Penelitian semiotika komunikasi bertujuan untuk menafsirkan pesan yang berupa tanda, baik tanda verbal maupun nonverbal. Semiotika dijelaskan oleh John Fiske ${ }^{13}$ sebagau studi tentang pertanda dan makna dari sistem tanda; ilmu tentang tanda, tentang bagaimana makna dibangun dalam teks media; atau studi tentang bagaimana tanda dari jenis karya apa pun dalam masyarakat yang mengkomunikasikan makna.

Semiotika menawarkan sebuah metode penelitian komunikasi yang dapat mengungkap pesan komunikasi, yang tidak semua pesan maknanya dapat dimengerti secara langsung. Banyak pesan komunikasi yang susah dipahami dan memiliki makna tersembunyi, dimana penelitian semiotika adalah menemukan makna laten. Sehingga tujuan utama penelitian semiotika komunikasi adalah menemukan tanda-tanda dalam teks dan yang terpenting memberi tanda-tanda itu makna.

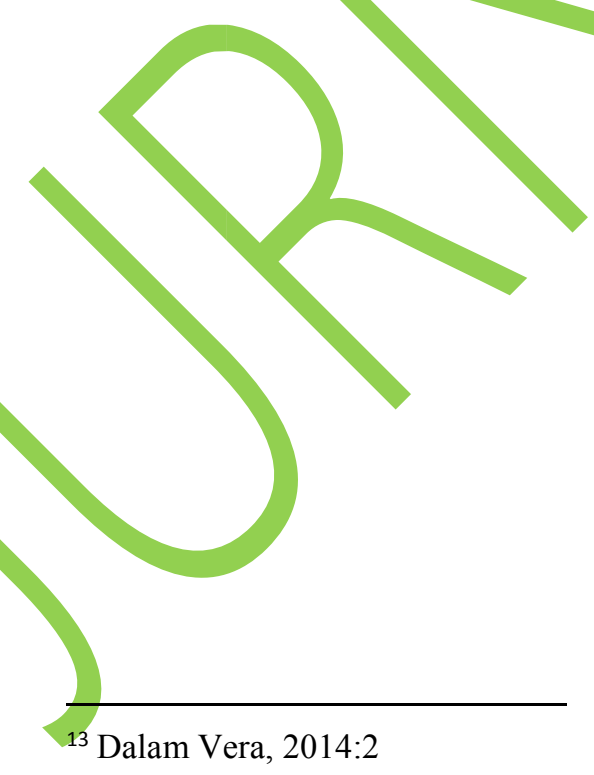




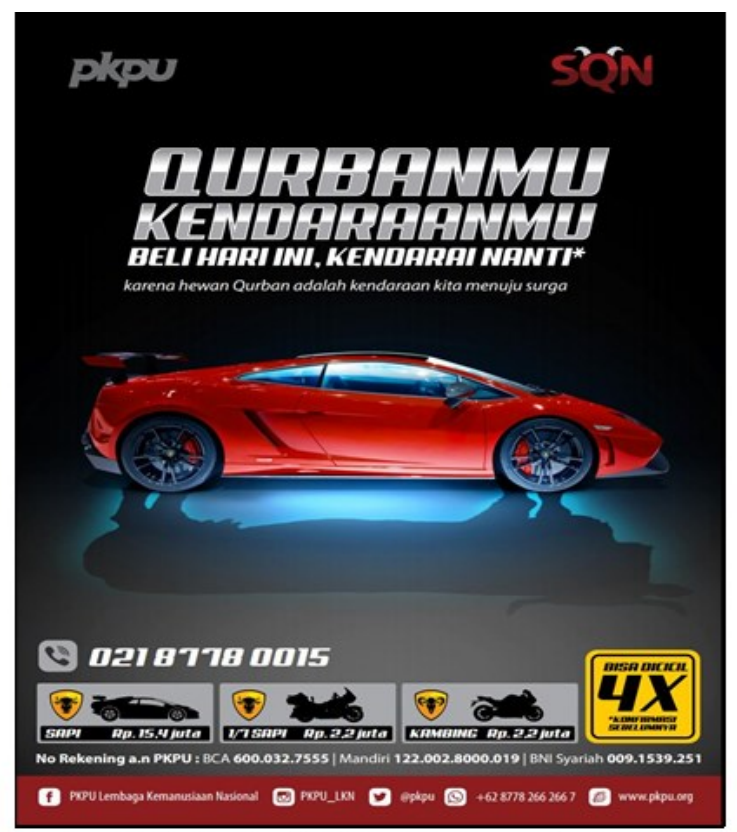

Gambar 1. Iklan Qurban PKPU Versi Qurbanmu Kendaraanmu -

\section{Teknik Pengumpulan Data}

Guna mendukung untuk keperluan menganalisa makna visual pada iklan kurban PKPU versi Mobil Sport di media cetak, penulis membutuhkan data-data yang mendukung baik dari buku-buku, majalah, internet, dan lainnya, yang berkaitan dengan judul yang penulis paparkan, dalam mengumpulkan data penulis melakukan dua macam pendekatan yaitu: data primer yang menggunakan teknik pengamatan non partisipasi tak berstruktur, serta data sekunder yang terdiri atas data penunjang yang dikumpulkan, dianalisa, dicatat dari data yang sudah tersedia sebagai pelengkap untuk melancarkan penelitian. Data dimaksud adalah melalui studi kepustakaan atau studi literaturdari sumber seperti, buku-buku, majalah, catatan, blog internet dan lain sebagainya, serta data lainnya yang diperoleh dari dokumen-dokumen pendukung, serta bahan-bahan lainnya sebagai bahan referensi. 


\section{Teknik Analisis Data}

Teknik Analisis yang digunakan dalam penelitian ini adalah analisis semiotika. Dalam penelitian ini, pendekatan yang digunakan untuk mengkaji iklan PKPU adalah kerangka analisis semiotik yang dikembangkan oleh Roland Barthes.

\section{Validitas dan Reliabilitas}

Peneliti menggunakan triangulasi sebagai teknik untuk mengecek keabsahan data. Dimana dalam pengertiannya triangulasi adalah teknik pemeriksaan keabsahan data yang memanfaatkan sesuatu yang lain dalam membandingkan hasil wawancara terhadap objek penelitian (Meleong, 2004:330). Triangulasi dapat dilakukan dengan menggunakan teknik yang berbeda (Nasution, 2003:115) yaitu wawancara, observasi dan dokumen. Triangulasi ini selain digunakan untuk mengecek kebenaran data juga dilakukan untuk memperkaya data. Menurut Nasution, selain itu triangulasi juga dapat berguna untuk menyelidiki validitas tafsiran peneliti terhadap data, karena itu triangulasi bersifat reflektif.

\section{Hasil Analisis dan Pembahasan}

\section{Deskripsi Iklan Cetak Qurban PKPU}

Iklan Qurban-MU Kendaraan-Mu dari PKPU versi Mobil Sport digunakan sebagai konten iklan di medio tahun 2016, versi iklan ini terdiri dari beberapa versi diantaranya versi Motor Besar dan Mobil Sport. Iklan ini digunakan untuk beberapa medium diantaranya untuk medium cetak, medium elektronik, dan medium - cetak - luar ruang. Dalam iklan cetak PKPU versi Mobil Sport terdapat dua versi yaitu dalam bentuk audio visual dan bentuk visual cetak. Dalam analisa iklan kurban PKPU versi Mobil Sport ini menggunakan versi iklan yang digunakan di media luar ruang PKPU dan beberapa media lainnya seperti media cetak dan website. Hal yang menarik dalam mencermati pemanfaatan iklan dalam konteks hewan kurban dimana iklan kurban - kebanyakan - mengedepankan fungsi informatif dibandingkan fungsi persuasif. Tetapi hal yang menarik dari iklan kurban PKPU versi Mobil 
Sport selain tetap menghadirkan fungsi informatif, tetapi juga memperkuat fungsi persuasifnya. Iklan kurban pun biasanya mengedepankan warna, dan simbol atau tanda yang mewakili aspek religius atau ke-Islam-an, akan tetapi berbeda dengan iklan kurban PKPU, termasuk versi Mobil Sport yang menggunakan warna dan tanda yang cenderung tidak menggunakan tanda yang biasa digunakan dalam iklan ibadah kurban. Biasanya warna putih dan hijau mendominasi, dan simbol-simbol yang berbau religius dan atau spirituil yang dikedepankan.

Iklan PKPU versi Mobil Sport menampilkan visual sebuah mobil sport berwarna merah, secara sepintas mobil ini mewakili sebuah merek ikonik di Italia meskipun tidak secara spesifik dimunculkan dalam iklan ini. Tanda atau simbol mobil ini menjadi fokal poin atau titik pusat dari layout iklan cetak tersebut. Selain mobil sport, juga ditampilkan sebuah silhouette atau bayangan hewan kurban yang dimunculkan di bawah gambar mobil sport tersebut. Di bagian pojok kiri atas dimunculkan logo PKPU dan di pojok kanan atas muncul logo SQN. Berdasarkan data yang diambil dari website resminya ${ }^{14}$ PKPU sendiri adalah kepanjangan dari Pos Keadilan Peduli Umat, sebuah lembaga amal kemanusiaan yang bermula ketika krisis yang terjadi pada 1997 mempengaruhi kondisi perekonomian bangsa dan rakyat Indonesia. PKPU dalam menjalankan program penyebaran daging kurban kepada masyarakat yang berhak dibuat program SQN atau Sebar Qurban Nusantara yang diselenggarakan sejak tahun 2000.

Sebagai bentuk respon dari krisis tersebut maka didirikan PKPU sebagai wadah aksi sosial, bermula pada tanggal 17 September 1998, seiring waktu pada 10 Desember 1999 lahirlah lembaga sosial yang bernama PKPU. Dalam perkembangannya PKPU menyadari bahwa potensi dana umat yang berasal dari Zakat, Infaq dan Shadaqah sangat besar. Sebagai negara berpenduduk muslim terbesar di dunia, Indonesia bisa mengoptimalkan dana ZIS-nya untuk memberdayakan masyarakat miskin. Pada tanggal 8 Oktober 2001,

\footnotetext{
14 www.pkpu.org
} 
PKPU mendapat pengukuhan sebagai Lembaga Amil Zakat Nasional sesuai dengan SK. Menteri Agama RI No 441.

Tanda lain yang dimunculkan dalam layout iklan adalah teks headline "Qurbanmu Kendaraanmu” dengan sub heading "Beli Hari Ini, Kendarai Nanti : karena hewan kurban adalah kendaraan kita menuju surga". Tanda lainnya adalah kotak kuning bertuliskan "Bisa Dicicil 4x * konfirmasi sebelumnya". Sedangkan di sisi kirinya muncul tiga kotak dengan tanda dan tulisan yaitu sapi dilambangkan mobil sport , 1/7 sapi dilambangkan motor besar, dan kambing yang dilambangkan dengan motor sport. Dalam kotak tersebut juga dimunculkan harga. Tetapi yang menarik adalah logo atau simbol yang digunakan untuk melambangkan sapi dan kambing, logo kuning yang sepintas identik dengan sebuah merek otomotif di Italia. Sedangkan tanda-tanda lain yang dimunculkan lebih terkait dengan informasi umum seperti nomor kontak, alamat email, dan alamat media sosial PKPU.

\section{Identifikasi, Analisis, dan Interpretasi Tanda dalam Iklan Cetak Qurban PKPU}

Identifikasi tanda dilakukan untuk menemukan tanda-tanda apa saja yang memiliki makna di iklan cetak kurban PKPU versi Mobil Sport. Setelah itu, untuk menganalisa lebih jauh tentang iklan kurban, peneliti akan menganalisa tampilan iklan cetak PKPU tersebut dari sudut pandang semiotika Roland Barthes.

Barthes membagi dua tahap signifikansi dimana tahap pertama mengungkap makna denotatif dari sebuah tanda, dan tahapan kedua mengungkap mengenai makna konotatif yang dimiliki tanda tersebut. Tanda sebagaimana dipahami oleh Barthes dapat diungkap pemaknaannya dari sudut pandang pembaca tanda, bukan hanya berdasar kepada maksud si pemilik tanda. "Kematian Sang Penulis" istilah singkat yang digunakan oleh Barthes memberikan sebuah kewenangan bagi pembaca pesan dalam memberikan pemaknaan atas sebuah pesan. Makna baik yang sudah terungkap (denotatif) maupun yang terselubung (konotatif), sebuah selubung yang menurut Barthes adalah sebuah politisasi atau realita opresif dari kekuasaaan atau dominasi pembuat pesan. 
Makna konotatif lebih lanjut dijelaskan oleh Barthes sebagai sebuah inti yang perlu diperbincangkan khususnya dalam semiotika, yang harus dimampukan untuk mengungkap makna-makna terselubung tersebut. Sebuah cara berpikir, cara berbicara, cara yang mengarahkan. Barthes menyatakan mitos yang berlaku - mitos yang bukan tahayul semata - di masyarakat merupakan sebuah cara pandang yang mengarahkan, dalam konteks komunikasi khususnya bahasa, penggunaan bahasa tertentu mencerminkan "sesuatu" nilai di baliknya. Barthes memberikan sebuah analisa berbeda bagaimana sebuah pesan yang secara denotatif memiliki makna "jelas", dapat diungkap memiliki sebuah makna lain (konotatif).

Dalam penelitian ini elemen-elemen yang terdapat pada iklan cetak PKPU mengenai kurban versi Motor Sport, disebut sebagai tanda (baik itu dari warna yang digunakan, pilihan bentuk logo yang dipakai, pengemasan keseluruhan, dan atau elemen-elemen lainnya yang menyatu menjadi sebuah acuan pemaknaan atas suatu objek. Untuk lebih jelasnya peneliti mengupas satu persatu dari bagian-bagian tersebut, sehingga mampu mengungkap makna konotatif maupun makna denotatif dalam iklan PKPU tersebut, dengan menggunakan peta tanda Barthes, dua tahapan signifikansi, serta analisa mendalam untuk mengungkap ideologi yang berjalan dalam tanda-tanda iklan tersebut. Berikut ini merupakan paparan dari analisa Barthes dalam menganalisa iklan cetak PKPU kurban versi Mobil Sport.

Untuk memudahkan pemaparan dalam pembahasan ini maka peneliti akan menmbagi analisa berdasarkan beberapa elemen yang dianggap signifikan dalam mengungkap makna dalam tanda pada iklan PKPU. Elemen anatomi iklan cetak yang menjadi unit analisa dibagi dalam dua pemaparan berdasarkan tahap signifikansi dalam Peta Tanda Barthes, yaitu signifikansi tahap pertama dan signifikasnis tahap kedua.

Pada analisa signifikansi tahap pertama akan disampaikan atas tiga aspek yaitu teks (termasuk penggunaan warna), layout, dan visualisasi yang digunakan. Dalam aspek visual terdiri atas beberapa bagian yaitu : Aspek visual utama, yaitu bagian utama yang menjadi fokus tengah dari layout iklan yaitu gambar Mobil Sport dan silhouette bayangan hewan. 
Sebuah gambar mobil sport berwarna merah digunakan sebagai penyampai pesan utama “Qurban-Mu Kendaraan-Mu”. Secara makna denotatif petanda mobil sport menjadi penguat dari penanda kendaraan. Sebuah relasi antara penanda dan petanda yang menurut peneliti mengungkapkan secara gamblang bagaimana mobil adalah kendaraan. Proses signifikansi ini menjadi lebih menarik ketika mengungkap makna konotatif dari gambar mobil sport, khususnya ketika mobil sport ini disandingkan dengan silhouette hewan kurban. Menjadi sebuah justifikasi logis untuk pembaca untuk mengungkap makna konotatif iklan tersebut dimana "Qurban-mu Kendaraan-Mu" yaitu mobil sport sebagai petanda dari penanda amalan ibadah kurban sebagai sebuah kendaraan menuju surga, sesuai dengan pesan yang disematkan "Beli Hari Ini, Kendarai Nanti : karena hewan kurban adalah kendaraan kita menuju surga ". Menjadi makna konotatif yang gamblang dapat dibaca. Selain itu penggunaan warna dominan, dalam hal ini merah menunjukkan mobil sport sebagai titik utama - sesuai dengan posisi layotu yang berada di tengah iklan - dari iklan tersebut, kontras dengan warna latar yang cenderung gelap. Warna ini pun selaras dengan pesan "kekinian" yang coba disampaikan oleh PKPU melalui iklan kurban versi Mobil Sport.

Aspek visual pendukung yang dianalisa yaitu bagian atas layout dan bagian bawah layout. Pada bagian atas terdapat : logo PKPU dan SQN yang menjadi tanda dari pembuat pesan iklan, dimana tidak akan dijelaskan oleh peneliti. Aspek lain yang muncul adalah pada bagian bawah yaitu : kotak di pojok kanan bawah yang betuliskan "Bisa dicicil 4x*" dengan warna kuning dominan, serta tulisan " *konfirmasi sebelumnya". Sebuah tanda yang secara denotatif menunjukkan bagaimana PKPU mengakomodir kebutuhan untuk mereka yang akan berkurban dengan kemudahan mencicil, sebuah relasi antara Penanda mencicil yang disematkan oleh Petanda teks "bisa dicicil $4 \mathrm{x}$ ". Pada tahap makna konotatif dapat dilihat lebih jauh bagaimana "bisa dicicil 4x" memunculkan sebuah hubungan penanda-petanda "kemudahan dalam menjalankan ibadah kurban", lebih jauh pemaknaan ini berkaitan erat dengan sebuah pemikiran bahwa ibadah kurban membutuhkan sebuah effort dari pelakunya salah satunya dari sisi pembiayaan (economic factor). 
Hukum ibadah kurban secara umum terbagi menjadi dua pendapat utama pertama sebagai sebuah ibadah yang sifatnya sunat, misalnya mazhab Syafei hukum melakukan ibadah kurban adalah sunat muakkadah yaitu sunnah yang amat digalakkan atau dituntut ke atas setiap individu Muslim yang merdeka, berakal, baligh lagi rasyid serta berkemampuan melakukannya sama ada sedang mengerjakan haji ataupun tidak sekurangkurangnya sekali seumur hidup ${ }^{15}$. Dan pendapat lain yang menyatakan hukum kurban adalah wajib bagi mereka yang memiliki kelapangan (kemampuan) ${ }^{16}$. Dikaitkan kembali

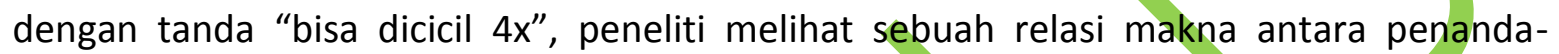
petanda untuk mengungkap makna konotatif pesan iklan tesebut, peneliti melihat sebuah pesan konotatif dimana ibadah kurban yang mebutuhkan sebuah upaya ekonomi dipermudah oleh PKPU dengan cara mencicil, sehingga secara sederhana PKPU mengirimkan pesan bahwa beribadah kurban itu mudah. PKPU secara tidak langsung memampukan mereka yang sejatinya belum mampu untuk melakukan ibadah kurban.

Sedangkan pada bagian bawah pojok kiri terdapat tiga kotak dengan tanda dan tulisan yaitu sapi dilambangkan mobil sport, 1/7 sapi dilambangkan motor besar, dan kambing yang dilambangkan dengan motor sport, berikut sebuah nominal rupiah yang muncul. Secara lugas simbol, tulisan dan warna kuning yang digunakan adalah untuk mempertegas bahwa terdapat beberapa pilihan untuk melakukan ibadah kurban sesuai dengan syariat. Dalam tataran makna konotatif diperlihatkan bagaimana sebuah "bahasa ekonomi" digunakan untuk memberikan sebuah gambaran bagaimana keterkaitan antara besaran hewan kurban dengan analogi kendaraan yang digunakan sebagai simbol, bagaimana sapi

\footnotetext{
${ }^{15}$ Pendapat mayoritas ulama yaitu Malik, Syafi'i, Ahmad, Ibnu Hazm dan lain-lain. Ulama yang mengambil pendapat ini berdalil dengan riwayat dari Abu Mas'ud Al Anshari radhiyallahu 'anhu. (lihat Shahih Fiqih Sunnah, II/367-368, Taudhihul Ahkaam, IV/454), sumber : http://muslim.or.id/446-fiqih-qurban.html

${ }^{16}$ Ulama yang berpendapat demikian adalah Rabi'ah (guru Imam Malik), Al Auza'i, Abu Hanifah, Imam Ahmad dalam salah satu pendapatnya, Laits bin Sa'ad serta sebagian ulama pengikut Imam Malik, Syaikhul Islam Ibnu Taimiyah, dan Syaikh Ibnu 'Utsaimin rahimahumullah. (HR. Ibnu Majah 3123, Al Hakim 7672 dan dihasankan oleh Syaikh Al Albani), sumber : http://muslim.or.id/446-fiqih-qurban.html
} 
dianggap utama, lebih mahal, lebih cepat, lebih keren sebagaimana layaknya sebuah mobil sport. Analogi yang sama dibangun dalam signifikansi motor besar dan motor sport. Sebuah makna sinonim bahwa "jika mampu" kenapa tidak ditunjukkan kemampuan tersebut dalam beribadah, khususnya dalam ibadah kurban. Dikaitkan dengan teks "Qurban-Mu Kendaraan-Mu" terbagun sebuah pemaknaan konotatif bahwa dengan memilih hewan kurban yang lebih mahal maka "kadar" nya menjadi lebih baik dibandingkan dua lainnya, sebagaimana penggunaan simbol mobil sport lebih "keren" dari motor besar dan motor sport. Penggunaan warna kuning atau cerah menunjang untuk mempertegas informasi (eye cathing), karena penempatan atau layout yang cenderung tidak dominan yaitu di pojok kiri bawah.

Hal yang menarik dalam penggunaan tanda dalam iklan ini khususnya pada bagian tiga kotak sapi, 1/7 sapi, dan kambing ini memberi kesan kuat tentang keutamaan hewan kurban berdasarkan kelasnya. Digambarkan secara "ranking", meskipun dalam hal tertentu pemaknaan ini bertemtangan dengan semangat dasar ibadah kurban yang mengutamakan ketakwaan umat kepada Allah SWT ${ }^{17}$

Pembahasan berikut akan melihat pada analisa signifikansi tahap kedua, mengungkap peran ideologi yang terkandung dalam pesan iklan kurban PKPU versi Mobil Sport. Peneliti melihat bagaimana penggunaan tanda-tanda dalam iklan tersebut mengandung sebuah ideologi tertentu, yang secara sepintas tampak bertentangan dengan makna pesan secara harfiah. Peneliti melihat mobil sport sebagai tanda utama yang digunakan dalam iklan ini mengandung sebuah makna yang kental terkait dengan konsumerisme. Mobil sport secara harfiah adalah sebuah kendaraan yang berkualitas premium. Secara jelas pun mobil sport memiliki harga yang sebanding dengan kualitas premium yang dimilikinya. Tetapi jika dianalisa secara mendalam dalam perspektif sosial

17 "Daging-daging unta dan darahnya itu sekali-kali tidak dapat mencapai (keridhaan) Allah, tetapi ketakwaan dari kamulah yang dapat mencapainya." (QS Al Hajj, 22: 37) 
mobil sport menjadi sebuah simbol kemapanan, sebuah simbol pride, bukan untuk orang sembarang. Penggunaan warna merah sebagai warna mobil sport semakin mempertegas dominasi yang secara tidak sadar dihadirkan dalam iklan ini. Sebuah komodifikasi dari nilai harga diri, eksklusif yang diwakili oleh sosok mobil sport berwarna merah, sebuah bentuk pernyataan dari pemilik atau pengendara mobil ini "Saya Istimewa". Dengan "keistimewaan" yang tersemat ini bukankah layak untuk saya untuk mendapat keistimewaan juga di dalam beribadah, pun secara dramatis peneliti melihat bahwa sebuah penyematan ideologi konsumerisme, sebuah bentuk komodifikasi nilai sebagaimana disebutkan oleh Baudrillard melalui konsep symbolic value dan use value digunakan dengan cantik, membeli mobil sport menjadi sebuah pilihan utama untuk mereka yang ingin diutamakan. Mobil sport sebagai sebuah bentuk pernyataan diri.

Dalam analisa semiotik Barthes terkait dengan mitos, secara nyata peneliti melihat sebuah relasi antara Penanda dan Petanda yang memunculkan makna konotatif pada tataran signifikansi tahap kedua dimana nilai konsumerisme hadir melalui penggunaan mobil sport sebagai ikon utama dalam iklan ini. Konsumerisme menjadi mengemuka justru ketika dikaitkan dengan teks "Qurban-Mu Kendaraan-Mu" dengan sub heading "Beli Hari Ini, Kendarai Nanti : karena hewan kurban adalah kendaraan kita menuju surga ". Ada sebuah signifikansi dimana menggunakan mobil sport sebagai sebuah kendaraan tentu akan menghantarkan kepada sebuah tujuan dengan segala kelebihannya dibandingkan dengan moda transportasi lain, misalnya dalam hal ini diperbandingkan dengan motor. Lebih lanjut penggunaan mobil sport yang secara sepintas mirip dengan mobil sport Ferarri dan atau Lamborghini, yang secara nyata menjadi simbol dari sebuah status sosial. Signifikansi ini secara jelas menempatkan symbolic value yang menjadi core dari konsep konsumerisme ketika konsumsi dilakukan bukan dalam konteks kebutuhan semata melainkan dalam kontek mengkonsumsi tanda.

Ideologi atau cara pandang, cara pikir, yang berlaku di masyarakat, menurut Barthes adalah mitos yang dapat diungkap - berbeda dengan sebuah kepercayaan yang bersifat 
tahayul, unlogical, ahistoris, ngawur - justru mitos merekam bagaimana cara pandang yang hadir melekat dalam sebuah masyarakat, sebuah "cara berbicara/berkomunikasi" yang melekat dalam sendi masyarakat baik disadari maupun tidak. Entah disengaja pun tidak. Mitos masyarakat konsumsi yang mengedepankan symbolic value semakin kental ketika gambar mobil sport disandingkan dengan tiga kotak mobil sport, motor besar, dan motor sport, serta "bisa dicicill4x". Sebuah pesan yang biasa disematkan dalam konteks ekonomi, sebuah pola konsumsi yang hadir dalam sebuah masyarakat konsumtif. Kata "cicil" menegaskan bagaimana sebuah konsepsi berpikir konsumtif, dimana komoditas diambil manfaatnya untuk kemudian cost dibayarkan kemudian, berbeda dengan penulisan kata "Tabungan atau Saving" yang menekankan pada proses dan manfaat, dimana proses menabung dilakukan untuk kemudian dijadikan sebagai bentuk biaya dalam memperoleh imbal hasil. Kata cicil identik dengan pola konsumsi masyarakat urban yang terkontaminasi kesegeraan. Budaya instan dalam meraih manfaat. Meski memang secara prosedural peneliti tidak menelaah lebih jauh mengenai syarat dan kondisi dalam melakukan proses cicilan hewan kurban di PKPU, tetapi yang ditekankan justru "way of speech" yang digunakan dalam iklan tersebut.

Terkait dengan simbol tiga kotak mobil sport, motor besar, dan motor sport, pun menarik untuk mengungkap ideologi konsumerisme yang terkandung di dalam iklan ini. Penempatan mobil sport dengan nominal rupiah terbesar diposisikan di pojok kanan, sebuah posisi yang secara subliminal menjadi simbolisasi ranking, lebih baik dibandingkan sesudahnya. Posisi kedua ditempati motor harley, dan ketiga oleh motor sport. Sebuah makna yang muncul bahwa posisi pertama "lebih" dibandingkan posisi dua lainnya. Penambahan logo atau tanda yang memunculkan sapi dan kambing menjadi menarik karena identik dengan logo Ferarri - meski ferarri menggunakan lambang kuda - dalam konteks kreatif tidak ada yang dipersalahkan dari penggunaan lambang tersebut, tetapi ketika dikaitkan dengan keseluruhan tanda di dalam iklan tersebut menjadi sangat kentara "bau" konsumerisme di dalamnya. Penggunaan lambang seperti logo Ferarri ini menjadi 
sebuah kesatuan yang tidak terpisahkan dengan keberadaan simbol mobil sport yang sekali lagi sama dengan Ferarri. Sehingga secara keseluruhan simbol yang berkaitan dengan mobil sport eksklusif ini sangat dominan digunakan dalam iklan hewan kurban PKPU versi mobil sport.

Teks "headline "Qurbanmu Kendaraanmu" dengan sub heading "Beli Hari Ini, Kendarai Nanti : karena hewan kurban adalah kendaraan kita menuju surga " ketika direkatkan dalam sebuah bingkai signifikansi tahap kedua Barthes memunculkan sebuah makna konotatif yang mengandung ideologi konsumerisme. Menunjukkan bagaimana tanda-tanda yang digunakan melalui mobil sport, motor besar, dan motor sport. Ditambah dengan simbol lainnya seperti "bisa dicicil $4 \mathrm{x}$ " menjadi sebuah makna dalam beribadah kurban, pilihan hewan menjadi penting dalam konsumsi nilai atau simbol, penempatan symbolic value menjadi hal utama dalam melakukan kurban. Membeli sapi sama dengan memakai mobil sport, yang "lebih" daripada satu per tujuh sapi, dan tentunya "lebih" dari motor sport. "Lebih" yang dapat dimaknai dalam pengertian konsumerisme, sebagai sebuah bentuk konsumsi tanda, sebuah pernyataan atau statement diri. Ketika dikaitkan dengan teks secara konotatif dalam signifikansi tahap pertama muncul relasi penanda-petanda dimana mobil sport menjadi penegas dari penanda "kendaraan" dalam berkurban, tetapi lebih jauh dalam pemaknaan tahap kedua, muncul sebuah mitos yang sarat dengan ideologi konsumerisme, dimana mobil sport menjadi "utama" karena lebih bergengsi, lebih jauh ada kesan bahwa kualitas fisik ini yang menjadi penentu dari kadar beribadah, sehingga terkesan mobil sport "lebih cepat sampai ke surga". Pemaknaan ini tentu berlawanan dengan makna sebenarnya dari ibadah kurban yang tidak mengedepankan kualitas materiil melainkan kualitas ibadah imateriil (niat dan ketakwaan) serta kurban sebagai bentuk penghambaan diri terhadap yang Maha Kuasa, serta bentuk syukur atas rezeki. Justru muncul sebuah mitos yang kontradiktif dimana iklan sebagai bentuk nyata dari budaya populer, lebih spesifik sebagai produk dari konsumerisme, tampak jelas bagaimana fungsi iklan dalam mempersuasi mind konsumen sehingga diharapkan terjadi perubahan perilaku. 
Persuasi dengan menampilkan sebuah gambaran-tanda-simbol tertentu, sehingga memunculkan sebuah persepsi-pemaknaan terhadap objek yang menjadi fokus dalam konten iklan. Tetapi yang menjadi titik utama analisis semiotika ini adalah bagaimana konsumerisme menjadi ideologi yang muncul dalam iklan tersebut, dan kontradiktif dengan makna sebenarnya mengenai ibadah kurban. Terjadi sebuah komodifikasi ibadah kurban dengan mengedepankan kurban sebagai sebuah komoditas konsumsi tanda belaka. Kurban sebagaimana layaknya sebuah barang dan atau jasa.

\section{Penutup}

\section{Kesimpulan}

Kurban merupakan ibadah wajib menurut sebagian ulama dan sunnat muakkad menurut ulama yang lain, kurban erat kaitannya dengan aspek hubungan vertikal dengan Tuhan dan aspek hubungan horisontal dengan sesama manusia. Kurban mengandung aspek teologis dan aspek sosial Secara garis besar, penelitian ini bertujuan untuk menganalisa unsur semiotika dan mendeskripsikan makna dari tanda-tanda yang terdapat dalam iklan kurban PKPU versi Mobil Sport. Tanda-tanda tersebut dianalisa dan dimaknai menggunakan metode semiotika Roland Barthes, dan berdasarkan hasil penelitian yang telah diuraikan dalam pembahasan, maka dapat ditarik kesimpulan penelitian sebagai berikut: Pertama, unsur-unsur semiotika dalam iklan cetak ini yaitu pertama, aspek visual yang terdiri dari: mobil sport dan silhouette hewan kurban, dan dua gambar kotak, satu kotak "bisa dicicil 4x" dan tiga kotak sapi mobil sport, 1/7 sapi motor besar, dan kambing motor sport. Kedua, warna yang terdiri dari: warna merah pada mobil sport, kuning pada latar dalam kotak "bisa dicicil $4 x^{\prime \prime}$ dan kotak pilihan hewan kurban (sapi, 1/7 sapi, kambing), serta warna hitam pada latar dan warna perak pada tulisan headline dan subhead yang menggunakan gradasi perak dan putih. Ketiga, tulisan yang ada pada keseluruhan tampilan iklan tersebut.

Berdasarkan tanda-tanda yang terdapat didalam iklan tersebut, Peneliti memaknai bahwa PKPU mengajak semua khalayak-nya melalui pesan iklan kurban versi mobil sport 
untuk melakukan ibadah kurban. Pada tataran signifikansi tahap pertama makna denotatif antara penanda dan petanda memunculkan mobil sport dengan pesan kendaraan. Pada makna konotatif mobil sebagai kendaraan menjadi petanda dari amal ibadah dari kurban itu sendiri. Pada tataran signifikansi tahap kedua makna konotatif ibadah kurban melalui penanda mobil sport memunculkan sebuah ideologi konsumerisme sebagai mitos yang berlaku dalam iklan tersebut. Dimana makna atau signifikansi tersebut kontradiktif dengan pesan harfiah yang coba disampaikan melalui pesan ini.

\section{Saran}

Dengan dilakukannya penelitian ini, maka diharapkan bagi pembuat iklan atau pun peneliti selanjutnya untuk mempertimbangkan penggunaan tanda-tanda yang relevan dan selaras dengan pesan utama yang ingin diusung. Meski demikian analisa mitos dalam semiotika Barthes ini memunculkan sebuah fenomena menarik untuk ditelaah lebih lanjut dalam konteks akademik, terkait dengan pemanfaatan iklan dalam barang atau jasa yang berkaitan dengan nilai religi. Bagaimana budaya populer dan ideologi yang terkandung di dalam masyarakat memiliki pengaruh tertentu dalam cara pandang dalam memaknai objek tertentu. Dalam hal ini bagaimana komodifikasi agama menjadi sebuah realita yang tidak dapat dihindari di tengah gencarnya budaya konsumerisme yang semakin merebak. Adapun saran praktis terkait penelitian ini bagi pelaku periklanan khususnya bagian kreatif yang menangani iklan hewan kurban PKPU, agar mempertahankan dan mengembangkan ide atau konsep visual yang out of the box dan unik seperti ini. Meski perlu dipertimbangkan penggunaan tanda-tanda yang memang selaras dan relevan dengan pesan utama yang ingin disampaikan. 


\section{DAFTAR PUSTAKA}

Barthes, Roland (2012). Elemen-elemen Semiologi. Yogyakarta : Jalasutra

Barthes, Roland. (2007). Membedah Mitos Nitos Budaya Massa: Semiotika atau Sosiologi Tanda, Simbol, dan Representasi. Yogyakarta : Jalasutra

Baudrillard, Jean(2006). Ekstasi Komunikasi. Yogyakarta : Kreasi Wacana

Meleong, Lexy J. (2002). Metode Penelitian Kualitatif. Bandung: PT. Remaja Rosdakarya

Myers, Kathy (2012). Membongkar Sensasi dalam Godaan Iklan. Yogyakarta : Jalasutra

Nasution, Prof. Dr. S.(2003). Metode Penelitian Naturalistik Kualitatif. Bandung : Tarsito.

Sobur, Alex (2013). Semiotika Komunikasi. Bandung : PT. Remaja Rosdakarya

Shihab, M. Quraish (2002). Tafsir Al Mishbah: Pesan, Kesan dan Keserasian Al Quran. Jakarta: Lentera Hati.

Vera, Nawiroh (2014). Semiotika dalam Riset Komunikasi. Bogor : Penerbit Ghalia Indonesia.

\section{Situs :}

http://muslim.or.id/446-fiqih-qurban.html 